\title{
The effect of fermented tempeh aerobic anaerobic (FETAA) on pancreatic duodenal homeobox 1 (Pdx1) gene expression and HOMA-beta index in diabetic mice
}

\author{
Hendi Wicaksono ${ }^{1 *}$, Prasetyastuti ${ }^{2}$, Pramudji Hastuti ${ }^{2}$, Ahmad Hamim Sadewa ${ }^{2}$ \\ 'Duta Wacana Christian University, Jl. Dr Wahidin Sudirohusodo No 5- 25, Gondokusuman, Yogyakarta, Indonesia \\ 2Department of Biochemistry Faculty of Medicine, Public Health and Nursing, Gadjah Mada University, Jl. Farmako, Depok, \\ Sleman, Yogyakarta, Indonesia \\ "Corresponding author: Departement of Biochemistry, Duta Wacana Christian University, Jl. Dr Wahidin Sudirohusodo No 5-25, \\ Gondokusuman, Yogyakarta, Indonesia. Email: hendiwicaksono1@gmail.com
}

\begin{abstract}
Background: Diabetes is a result of oxidative stress which causes the impaired function of pancreatic beta-cells. Fermented tempeh aerobic anaerobic (FETAA) containing gamma-aminobutyric acid and isoflavones can reduce oxidative stress in diabetes.

Objective: The aim of this study is to evaluate FETAA in improving pancreatic $\beta$-cell function in diabetic mice.

Methods: Twenty streptozotocin-induced diabetic mice, divided into four groups ( $\mathrm{n}=5$ each group): DM, DM + FETAA $10 \mathrm{mg} / 100 \mathrm{~g} \mathrm{BW}$, DM + FETAA $20 \mathrm{mg} / 100 \mathrm{~g} \mathrm{BW}$, DM + FETAA $40 \mathrm{mg} / 100 \mathrm{~g}$ BW as well as normal group $(\mathrm{n}=5)$. DM mice were treated with FETAA for 21 days. Fasting glucose was determined using the GODPAP method, while insulin level was determined by ELISA. The homeostasis model assessment of $\beta$-cell function (HOMA- $\beta$ ) was calculated using the HOMA2 calculator, and the Pdx1 mRNA level was determined by Real Time-PCR.

Results: The DM mice group treated with FETAA had lower glucose levels than the DM mice group. FETAA dosage of $40 \mathrm{mg} / 100 \mathrm{~g}$ BW was able to reduce the highest blood glucose levels $(\mathrm{p}<0.05)$. DM mice group treated with FETAA had higher levels of insulin and HOMA- $\beta$ than the DM mice group $(p<0.05)$. Treatment of FETAA $10 \mathrm{mg} / 100 \mathrm{~g}$ BW produced the highest insulin content of $57.44 \pm 8.132 \mathrm{pmol} / \mathrm{L}$, while treatment of FETAA 40 $\mathrm{mg} / 100 \mathrm{~g}$ BW had a HOMA- $\beta$ value of $72.86 \pm 21.85 \%$. Pdx1 mRNA expression in group FETAA-treated DM mice was higher than the DM mice group, although it was not statistically significant ( $>0.05)$.
\end{abstract}

Conclusion: FETAA could improve HOMA- $\beta$, blood glucose levels, but did not affect Pdx1 mRNA expression.

Keywords: fermented tempeh aerobic anaerobic, gamma aminobutyric acid, HOMA-beta, pancreatic duodenal homeobox 1 , type 2 diabetes mellitus

\section{Introduction}

Diabetes mellitus (DM) has the third rank cause of death in Indonesia [1]. The number of DM patients has tended to increase in recent years. According to the International Diabetes Foundation (IDF), it is estimated that in 2035 the number of DM sufferers will be around 382 million worldwide [2]. More than $80 \%$ of DM patients are found in developing countries and $60 \%$ are found in Asia [3]. The majority of people with diabetes, among $90-95 \%$, are patient of type 2 diabetes and the prevalence rate of patients tends to increase in developing countries such as India, Brazil, Pakistan and Indonesia [4]. Treatment of type 2 diabetes mellitus is long-term, and has various side effects, such as long-term use of insulin secretagogues can damage pancreatic $\beta$-cells due to overstimulation [5].

Regeneration approach therapy is required in diabetes mellitus therapy. The regeneration of pancreatic $\beta$ cells can be achieved through two mechanisms, namely self-replication of pancreatic $\beta$ 
cells and conversion of $\alpha$ cells to $\beta$ cells. Regeneration of pancreatic $\beta$ cells in diabetes can occur through stimulation of several transcription factors, signal pathways, and mediators [6]. Gamma-aminobutyric acid (GABA) is known to be a substance that has the ability to repair and protect pancreatic $\beta$ cells [7]. Fermented tempeh aerobic anaerobic (FETAA) is fermented soybean products that are made by using a combination of aerobic and anaerobic fermentation methods. An anaerobic fermentation could increase the GABA content compared to traditional tempeh [8]. The combination method could increase the isoflavone content compared to traditional tempeh [9].

Pancreatic duodenal homeobox 1 (Pdx1) is the main transcription factor that plays a role in the process of organogenesis and regeneration of the pancreas [10]. Homeostatic model assessment (HOMA) is a formula to assess the function of pancreatic $\beta$-cells by correlating blood glucose and insulin balance [11]. The aim of this study is to evaluate FETAA in the improvement type 2 diabetes mellitus mouse by evaluating expression of the Pdx1 and HOMA- $\beta$ index.

\section{Methods}

\section{Preparation of fermented tempeh aerobic anaerobic}

Soybeans (Glycine max L.) Anjasmoro varieties originated from Indonesia were purchased. Rhizopus FNCC 6010 inoculum was obtained from the Food and Nutrition Culture Collection, IUC Food, and Nutrition Gadjah Mada University. About 1000 g of unhulled soybeans were soaked with tap water at room temperature for 24 hours. Then, soybeans were cooked with water that was used for soaking for 15 minutes in boiling water. The cooked soybeans were cooled down to $27^{\circ} \mathrm{C}$ and then subsequently dehulled the soybeans by mixing vigorously the suspension manual. The dehulled soybeans were soaked again in fresh tap water by following the first procedure.

Once cooled to room temperature, the cooked soybeans were fermented by inoculating a spore suspension (25 $\mathrm{mL}$ of spore suspension) into the cooked soybeans $(1 \mathrm{~kg})$. About $120 \mathrm{~g}$ of inoculated beans were packed into perforated polyethylene plastic bags and incubated aerobically for $20 \mathrm{~h}$ at $37{ }^{\circ} \mathrm{C}$ (traditional tempeh). Anaerobic incubation was then conducted by transferring all the packed soybeans into Oxoid AnaeroJar 2,5 L containing AnaeroGen 2,5 L (Thermo) and incubated for $23 \mathrm{~h}$ at $37^{\circ} \mathrm{C}$. Subsequently, the FETAA was then lyophilized using the BenchTop Pro with Omnitronics-Freeze dryer, USA, and then ground into a powder.

\section{Ethical clearance}

The animal experiments were approved by the Medical and Health Research Ethics Committee (MHREC) of Faculty of Medicine Gadjah Mada University (authorization number Ref. No: KE/ FK/0335/EC/2019) under the recommendations for handling animals for research.

\section{Animal model}

A total of 25 male Balb/c mice (8-10 weeks old; 26-30 g) were housed in polycarbonate cages with an artificial 12-h light/dark cycle at a constant temperature $\left(25^{\circ} \mathrm{C}\right)$. The mice were fed an AIN-93 M diet (D10012M-Research Diet, USA). Mice were acclimatized for seven days; then mice were randomly divided into non-diabetic (n $=5)$ and diabetic $(n=20)$ groups. The diabetic mice model was induced by a single injection of streptozotocin (STZ) $(50 \mathrm{mg} / \mathrm{kg}$ BW in $0,1 \mathrm{M}$ citrate buffer, pH 4,2; Sigma, St. Louis, MO, USA) into the peritoneum on two consecutive days. Nicotinamide (NA, 120 mg/kg BW; Sigma, St. Louis, MO, USA) was dissolved in saline and injected intraperitoneally 15 min before the administration of STZ [12]. The non-diabetic mice were injected with citrate buffer or saline alone. After five days, only STZ/NA-treated mice that exhibited a fasting blood glucose level of $\geq 196 \mathrm{mg} / \mathrm{dL}$ were used in the study.

The diabetic mice were randomly subdivided into four groups each group contained five mice: the diabetic group (DM), the diabetic given FETAA 


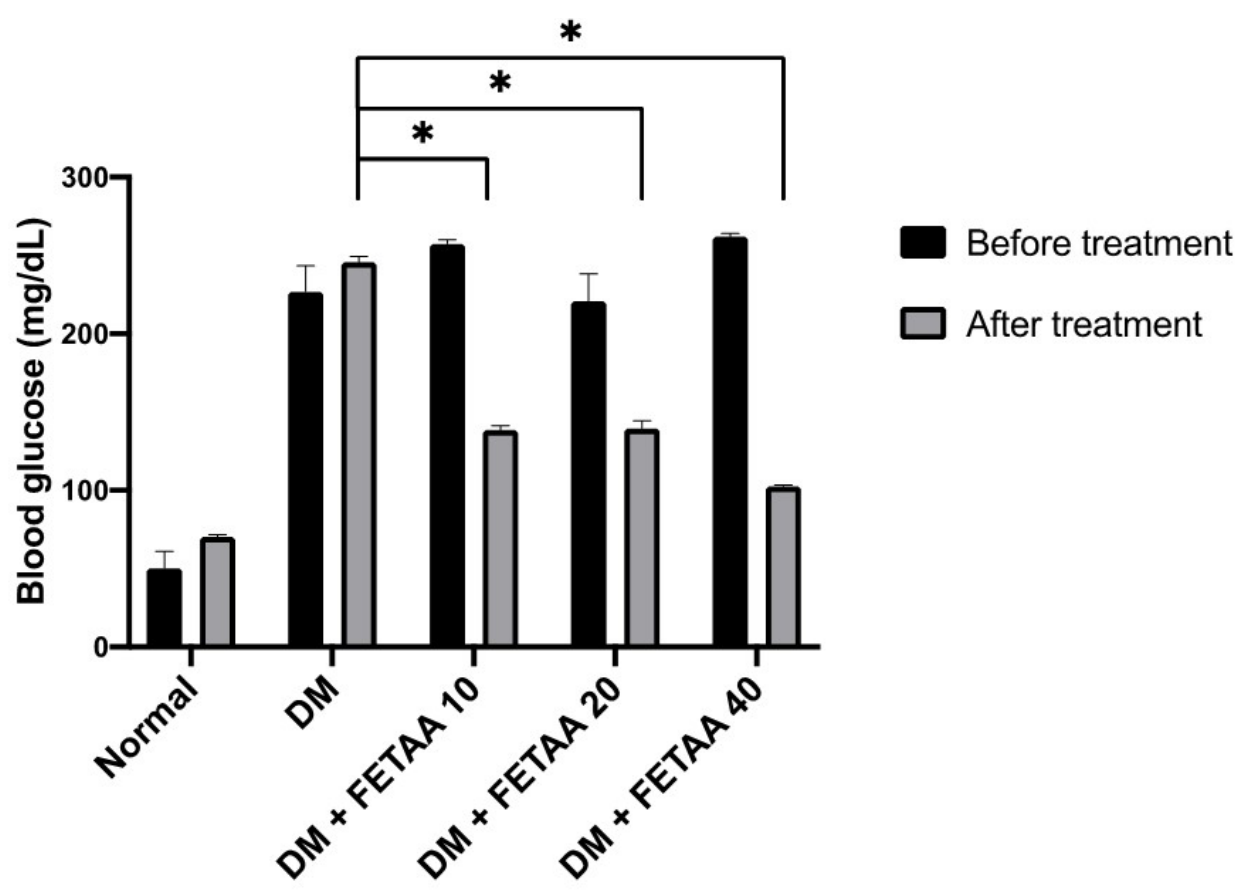

Figure 1. Total fasting blood glucose of treatment groups of mice. Statistical analysis used the One-way Anova test followed by the Howell Games post hoc test with ${ }^{*} p<0.05$ stated as significantly different

$10 \mathrm{mg} / 100 \mathrm{~g} \mathrm{BW}$ (DM + FETAA 10), the diabetic given FETAA $20 \mathrm{mg} / 100 \mathrm{~g}$ BW (DM+FETAA 20), the diabetic given FETAA $40 \mathrm{mg} / 100 \mathrm{~g}$ BW (DM + FETAA 40). The experiment was carried out for 21 days, at the end of the experimental period, the mice were then decapitated.

\section{The fasting blood glucose assay}

The fasting blood glucose concentration in serum was estimated with the GOD-PAP method using a glucose kit (DiaSys, Germany), and measured by spectrometry (SP-300, OPTIMA) with $500 \mathrm{~nm}$ wavelength. Blood samples were collected by retro-orbital vein, the experiment was carried out according to the manufacture's instruction.

\section{The insulin level assay}

Blood serum of mice was taken at the end of the experiment, analysis of insulin levels by Enzyme-Linked Immunosorbent Assay (ELISA) method using Mouse INS (Insulin) kit (Finetest, Wuhan) experiment was carried out according to the manufacturer's instruction.
The homeostasis model assessment for betacell function (HOMA- $\beta$ )

The homeostasis model assessment for $\beta$-cell function (HOMA- $\beta$ ) was calculated via the following equation: fasting serum insulin $(\mathrm{mU} / \mathrm{L}) \times 20 /$ fasting glucose (mmol/L) - 3,5 [13]. The calculation used the HOMA2 Calculator software obtained from the Diabetes Trial Unit (DTU), University of Oxford 2004-2019.

The mRNA Pdx1 expression analysis with the Real-Time PCR

Total RNA was isolated from the pancreas for cDNA synthesis by using RevertAid First Strand cDNA Synthesis Kit (Thermo Scientific, USA). The real-time PCR assay was performed by using ExcelTaq ${ }^{\text {TM }}$ 2X Fast Q-PCR Master Mix (SMOBIO, China). Primers used were as follows: Gapdh forward 5'-CGTGCGTGACATCAAAGAGAA-3', reverse 5'-TGGATGCCACAGGATTCCAT-3'; Pdx-1 forward 5'- GAGGTGCTTACACAGCGGAA -3', reverse: 5'- GGGCCGGGAGATGTATTTGT -3'. The thermal cycling profile was used (40 cycles): $95{ }^{\circ} \mathrm{C}$ for $20 \mathrm{~s}, 95{ }^{\circ} \mathrm{C}$ for $3 \mathrm{~s}, 60{ }^{\circ} \mathrm{C}$ for $30 \mathrm{~s}$. 


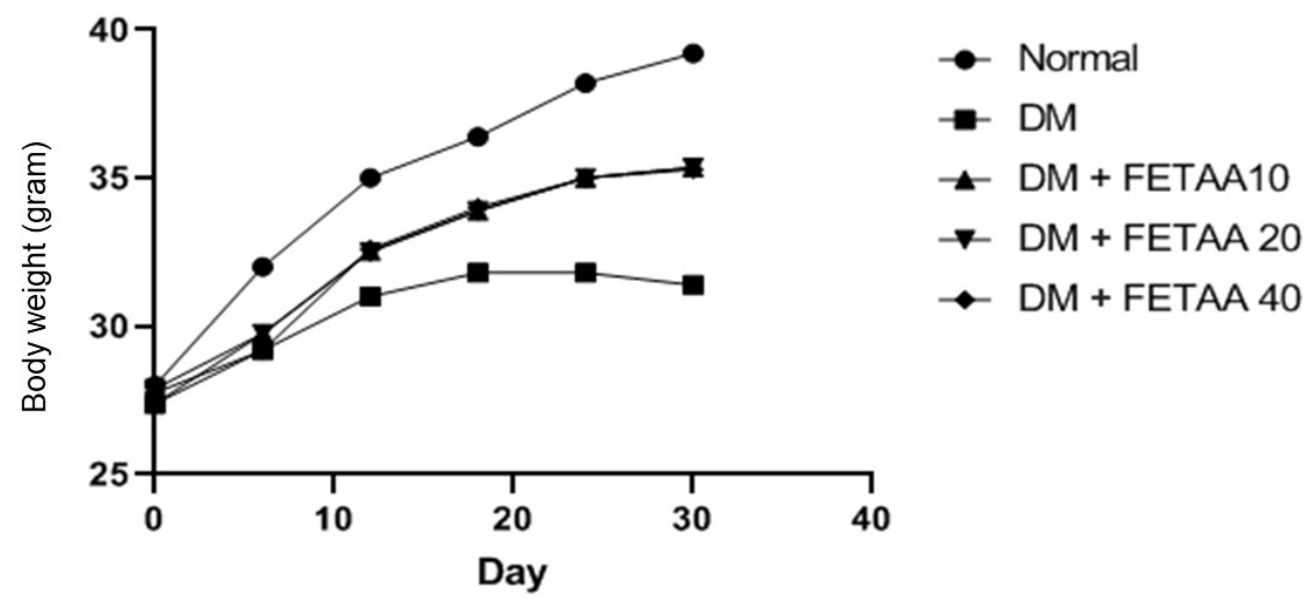

Figure 2. Curve of weight gain during experiment.

The ${ }^{{ }^{\Delta}} \mathrm{CT}$ relative quantification method was used to determine the fold change in expression by normalizing the CT values of the target mRNAs to the CT values of the internal control Gapdh in the same samples. Further, it was normalized with the control $\left({ }^{\Delta \Delta} \mathrm{CT}={ }^{\Delta} \mathrm{CT}_{\text {Treatment }}-{ }^{\Delta} \mathrm{CT}\right.$ Control $)$. The fold change in expression was then obtained as $2^{-\Delta \Delta C T}$.

\section{Data analysis}

The data were drawn with Graphpad Prism 8.0 (San Diego, California, USA) and were expressed as the mean \pm standard deviation. Statistical significance was analyzed by one-way analysis of variance followed Games Howell test. $\mathrm{p}<0.05$ was considered to indicate a statistically significant difference.

\section{Results}

\section{Determination of blood glucose and measurement of body weight}

The fasting blood glucose levels were elevated in mice on a 5-day post administrated with STZ/NA. In this study, STZ/NA-treated mice that exhibited a fasting blood glucose level of $\geq 196 \mathrm{mg} / \mathrm{dL}$ were used in the study. The fasting blood glucose concentration in diabetic mice was significantly higher than in the diabetic group that received FETAA supplementation during the 3 weeks. After 3 weeks, the fasting blood glucose levels on DM + FETAA 10 group, DM + FETAA 20 group, and DM +
FETAA 40 group were significantly lower than DM group $(\mathrm{p}<0.05)$ (Figure 1$)$. Results showed that the administration of FETAA in each treatment group could reduce blood glucose levels in mice. The administration of FETAA $40 \mathrm{mg} / 100 \mathrm{~g}$ BW was able to reduce blood glucose levels higher compared to the other group. We also noticed that the overall group has gained body weight (Figure 2).

\section{Effect of FETAA on insulin level}

Insulin is a hormone that plays important role in decreasing blood glucose to maintain normal blood glucose concentration [14]. In order to know the effect of FETAA on insulin level, we carried out an insulin level assay using ELISA. We found that insulin level in the group that received FETAA was higher compared to the normal group. The group that received FETAA dose $20 \mathrm{mg} / 100 \mathrm{~g}$ BW has the highest insulin level. These data suggest that FETAA administration could increase insulin levels (Figure 3).

\section{Effect of FETAA on HOMA- $\beta$ Index}

HOMA- $\beta$ index is an equation derived from fasting glucose and insulin level. HOMA- $\beta$ can be used to measure $\beta$ cell function in the pancreas [15]. We found that HOMA $\beta$ Index in DM + FETAA 10 group, DM + FETAA 20 group, and DM + FETAA 40 group were higher compared to the diabetic group. DM + FETAA 20 group showed significant 


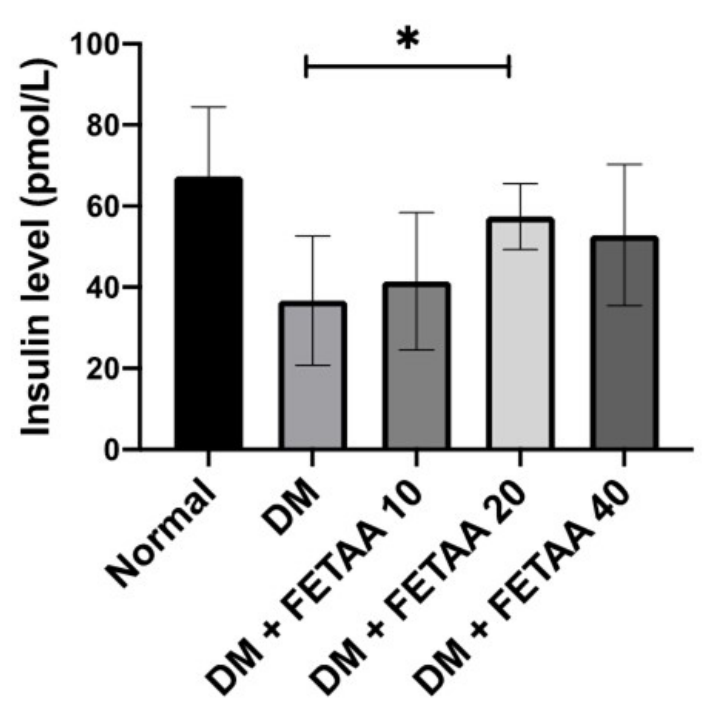

Figure 3. Insulin level. Statistical analysis using the One-way Anova test followed by the Howell Games post hoc test. *Express as significant $(p<0.05)$

differences compared to the DM group. These data suggest that supplementation of FETAA could improve $\beta$-cell function (Figure 4).

\section{Effect of FETAA on Pdx1 mRNA expression}

Pdx1 was an important transcription factor that plays role in the development and function of the $\beta$-cell pancreas [16]. In order to know the effect of FETAA on Pdx1 mRNA expression, we carried out a Real-Time PCR analysis. We found that the FETAA-treatment group expressed a higher level of Pdx1 mRNA than the DM group, although there is no statistically significant ( $p>0,05)$ (Figure 5).

\section{Discussion}

In this study, the administration of fermented tempeh aerobic anaerobic (FETAA) could decrease blood glucose levels. This result agrees with another study that stated consumption of fermented soybean can reduce body weight and reduce blood sugar levels in obese Wistar rats [17]. The possible mechanism is that isoflavones and soy protein can increase the secretion of the hormone peptide YY (PYY) which functions to stimulate satiety and prevent eating in mice and humans. Isoflavones also could reduce fat accumulation in the body and increase insulin resistance. Isoflavones compounds

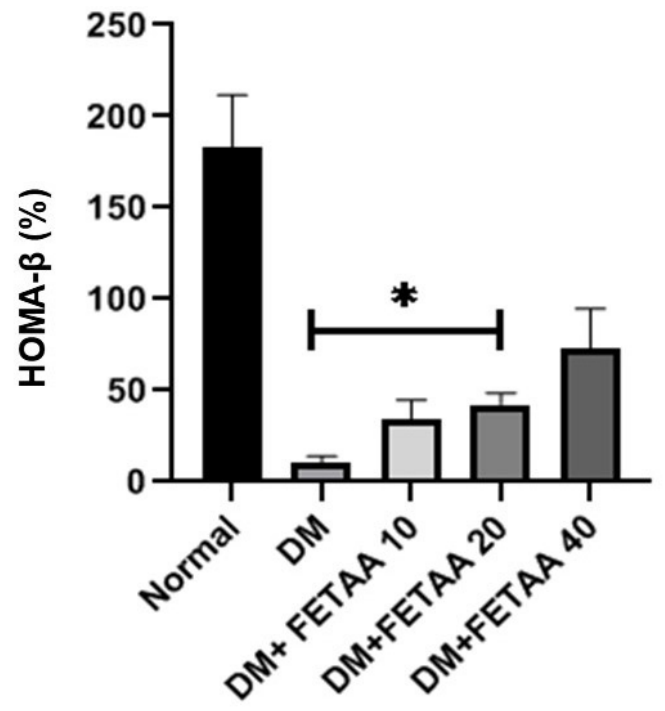

Figure 4. HOMA- $\beta$ index. Data were analyzed with One Way Anova. ${ }^{*} \mathrm{p}<0.05$

in soybean fermentation products also reduce glucose production in the liver by increasing insulin signaling in the liver [18]. Daidzein and genistein are examples of isoflavone in soybean and soybeans products [19]. One of the mechanisms underlying was the increase in IRS2 phosphorylation, which increase the phosphorylation of AKT and reduce insulin resistance in the liver [20]. Administration of FETAA dose $20 \mathrm{mg} / 100 \mathrm{~g}$ BW showed an increase in insulin level compared to the normal group. This result is consistent with research that giving tempeh and soy fermented milk is known to increase insulin secretion and reduce blood glucose levels in diabetic rats induced with streptozotocin [21].

The data analysis of the HOMA- $\beta$ index showed the group that received FETAA $20 \mathrm{mg} / 100 \mathrm{~g}$ BW had a higher HOMA- $\beta$ index compared to the diabetic group. The result is consistent with another research that consumption of soy-based foods in pregnant women with diabetes mellitus, show improved glucose homeostasis parameters (HOMA- $\beta$ and HOMA-IR), levels of oxidative stress, and the number of triglycerides [22]. In this study, HOMA- $\beta$ Index was low compare to the normal group. In another study showed that measuring HOMA- $\beta$ using insulin levels in serum is less representative of overall insulin levels due to 


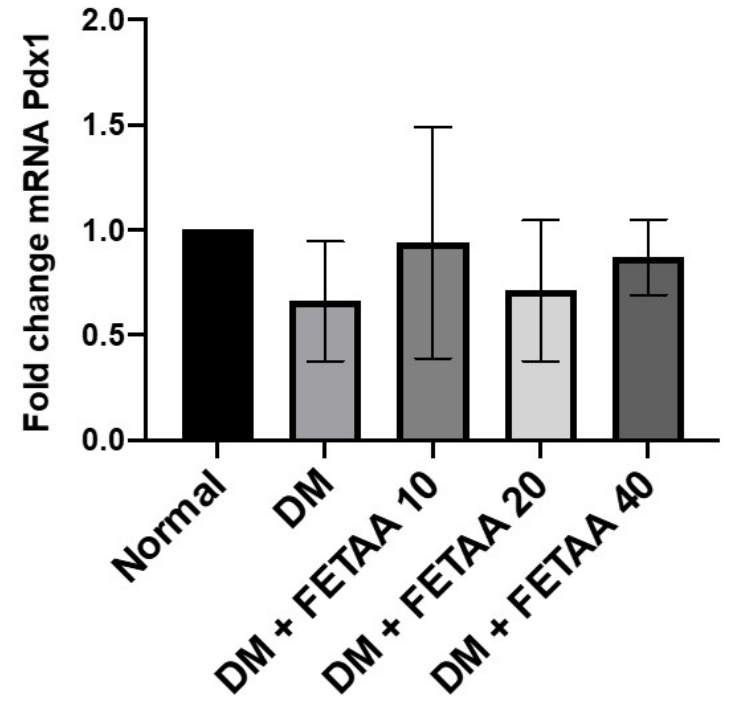

Figure 5. Fold change mRNA Pdx1. Statistical analysis using the One Way Anova test found no significant differences in each group $(p=0.37)$

the pattern of insulin secretion and short insulin half-life [23].

FETAA supplementation did not affect Pdx1 mRNA expression. Pdx1 is a transcription factor that plays important role in $\beta$-cell expansion and proliferation, which decreases the expression of Pdx1 expression could induce hyperglycemia [24]. Decrease of Pdx1 expression is known to be associated with decreased insulin content of $\beta$-cell and increase the susceptibility apoptosis of $\beta$-cell [25]. Other studies showed different results, the amino acid vglycin isolate from soybeans could increase the expression of the $P d x 1$ gene which plays a role in the proliferation of pancreatic $\beta$-cells [26], as well as other studies regarding the administration of chitosan nanoparticle-GABA in diabetic mice, it can increase $P d x 1$ gene expression compared with the diabetes group [27].

In this study, FETAA administration did not affect Pdx1 mRNA expression, although insulin levels in the group that received FETAA were higher than in the diabetic group. A possible mechanism according to a literature study regarding Psamommys obesus as a model of type 2 DM, suggested that the loss or reduced expression of the $P d x 1$ gene can be compensated by other transcription factors to stabilize insulin gene expression and to maintain insulin levels in the pancreas [28]. Another mechanism showed that Pdx1 expression does not directly affect $\beta$-cell mass and function [29]. In contrast to other studies on GABA which promotes $\beta$-cell proliferation in diabetic mice using $6 \mathrm{mg} / \mathrm{mL}$ GABA [30]. In the present study, several parameters such as insulin levels, HOMA- $\beta$ index, and Pdx1 mRNA expression showed an increase but were still not close to normal parameter values. The possible mechanism because the optimal dose of FETAA was not known. The limitation of this study is that it did not analyze the levels of active substances such as GABA and isoflavones in FETAA. It is necessary to develop other research using FETAA with different doses and different parameters.

\section{Conclusion}

Fermented tempeh aerobic anaerobic (FETAA) could improve HOMA- $\beta$ index, lower blood glucose levels but did not affect Pdx1 mRNA expression.

\section{Acknowledgment}

The authors would like to express gratitude toward Deta Intan Herdyan and Dian Setiawan Ghozali for their support and guidance in preparing the paper.

\section{Author contribution}

Conceptualization, H.W., P.; Methodology, H.W., P., P.H.; Investigation, H.W., P., P.H., A.H.S.; Resources, H.W., P.; Writing - Original Draft, H.W., P., P.H.; Writing - Review \& Editing, H.W., P.; Supervision, P.

\section{Decalaration of interest}

The authors declare no conflict of interest.

Received: 19 December 2020

Accepted: 24 August 2021

Published online: 28 August 2021

\section{References}

1. WHO WHO. Noncommunicable diseases country profiles 2018. World Health Organization; 2018.

2. Nanditha A, Ma RCW, Ramachandran A, Snehalatha C, 
Chan JCN, Chia KS, et al. Diabetes in asia and the pacific: implications for the global epidemic. Diabetes Care. 2016;39: 472-485. https://doi.org/10.2337/dc15-1536

3. Guariguata L, Whiting DR, Hambleton I, Beagley J, Linnenkamp U, Shaw JE. Global estimates of diabetes prevalence for 2013 and projections for 2035. Diabetes Res Clin Pract. 2014;103: 137-149. https://doi.org/10.1016/j. diabres.2013.11.002

4. Wu Y, Ding Y, Tanaka Y, Zhang W. Risk factors contributing to type 2 diabetes and recent advances in the treatment and prevention. Int J Med Sci. 2014;11: 1185-1200. https://doi.org/10.7150/ijms.10001

5. Choudhury H, Pandey M, Hua CK, Mun CS, Jing JK, Kong L, et al. An update on natural compounds in the remedy of diabetes mellitus: A systematic review. J Tradit Complement Med. 2018;8: 361-376. https:// doi.org/10.1016/i.jtcme.2017.08.012

6. Zhong F, Jiang Y. Endogenous pancreatic $\beta$ cell regeneration: A potential strategy for the recovery of $\beta$ cell deficiency in diabetes. Front Endocrinol (Lausanne). 2019;10: 101. https://doi.org/10.3389/fendo.2019.00101

7. Purwana I, Zheng J, Li X, Deurloo M, Son DO, Zhang $Z$, et al. GABA promotes human $\beta$-cell proliferation and modulates glucose homeostasis. Diabetes. 2014;63: 4197-4205. https://doi.org/10.2337/db14-0153

8. Aoki H, Uda I, Tagami K, Furuya Y, Endo Y, Fujimoto K. The production of a new tempeh-like fermented soybean containing a high level of gamma-aminobutyric acid by anaerobic incubation with Rhizopus. Biosci Biotechnol Biochem. 2003;67: 1018-1023. https://doi.org/10.1271/ $\underline{\text { bbb.67.1018 }}$

9. Mohd Yusof H, Ali NM, Yeap SK, Ho WY, Beh BK, Koh SP, et al. Hepatoprotective Effect of Fermented Soybean (Nutrient Enriched Soybean Tempeh) against Alcohol-Induced Liver Damage in Mice. Evid Based Complement Alternat Med. 2013;2013: 274274. https:// doi.org/10.1155/2013/274274

10. Minami K. GATA transcription factors: New key regulators in pancreas organogenesis. J Diabetes Investig. 2013;4: 426-427. https://doi.org/10.1111/jdi.12089

11. Cersosimo E, Solis-Herrera C, Trautmann ME, Malloy J, Triplitt CL. Assessment of pancreatic $\beta$-cell function: review of methods and clinical applications. Curr Diabetes Rev. 2014;10: 2-42. https://doi.org/10.2174/1573399 $\underline{810666140214093600}$

12. Lee J, Yee S-T, Kim J-J, Choi M-S, Kwon E-Y, Seo K-I, et al. Ursolic acid ameliorates thymic atrophy and hyperglycemia in streptozotocin-nicotinamide-induced diabetic mice. Chem Biol Interact. 2010;188: 635-642. https://doi.org/10.1016/j.cbi.2010.09.019

13. Garg MK, Dutta MK, Mahalle N. Study of beta-cell function (by HOMA model) in metabolic syndrome. Indian J Endocrinol Metab. 2011;15: S44-9. https:// doi.org/10.4103/2230-8210.83059
14. Qaid MM, Abdelrahman MM. Role of insulin and other related hormones in energy metabolism: A review. Cogent Food Agric. 2016;2. https://doi.org/10.1080/2331193 2.2016.1267691

15. Fu S, Zhou S, Luo L, Ye P. Relationships of pancreatic beta-cell function with microalbuminuria and glomerular filtration rate in middle-aged and elderly population without type 2 diabetes mellitus: a Chinese communitybased analysis. Clin Interv Aging. 2017;12: 753-757. https://doi.org/10.2147/CIA.S134496

16. Liu J, Lang G, Shi J. Epigenetic Regulation of PDX-1 in Type 2 Diabetes Mellitus. Diabetes Metab Syndr Obes. 2021;14: 431-442. https://doi.org/10.2147/DMSO.S291932

17. Lim KH, Han J-H, Lee JY, Park YS, Cho YS, Kang K-D, et al. Assessment of antidiabetogenic potential of fermented soybean extracts in streptozotocin-induced diabetic rat. Food Chem Toxicol. 2012;50: 3941-3948. https://doi. org/10.1016/j.fct.2012.08.036

18. Velasquez MT, Bhathena SJ. Role of dietary soy protein in obesity. Int J Med Sci. 2007;4: 72-82. https://doi. org/10.7150/ijms.4.72

19. Haron H, Ismail A, Azlan A, Shahar S, Peng LS. Daidzein and genestein contents in tempeh and selected soy products. Food Chem. 2009;115: 1350-1356. https:// doi.org/10.1016/i.foodchem.2009.01.053

20. Kwon DY, Hong SM, Ahn IS, Kim YS, Shin DW, Park S. Kochujang, a Korean fermented red pepper plus soybean paste, improves glucose homeostasis in $90 \%$ pancreatectomized diabetic rats. Nutrition. 2009;25: 790-799. https://doi.org/10.1016/j.nut.2008.12.006

21. Bintari SH, Putriningt ND, Nugraheni K, Widyastiti NS, Dharmana E, Johan A. Comparative Effect of Tempe and Soymilk on Fasting Blood Glucose, Insulin Level and Pancreatic Beta Cell Expression (Study on StreptozotocinInduced Diabetic Rats). Pakistan J of Nutrition. 2015;14: 239-246. https://doi.org/10.3923/pjn.2015.239.246

22. Jamilian M, Asemi Z. The effect of soy intake on metabolic profiles of women with gestational diabetes mellitus. J Clin Endocrinol Metab. 2015;100: 4654-4661. https:// doi.org/10.1210/jc.2015-3454

23. Álvarez-Nava F, Bastidas D, Racines-Orbe M, Guarderas J. Insulin Sensitivity and Pancreatic $\beta$-Cell Function in Ecuadorian Women With Turner Syndrome. Front Endocrinol (Lausanne). 2020;11: 482. https://doi. org/10.3389/fendo.2020.00482

24. Jara MA, Werneck-De-Castro JP, Lubaczeuski C, Johnson JD, Bernal-Mizrachi E. Pancreatic and duodenal homeobox-1 (PDX1) contributes to $\beta$-cell mass expansion and proliferation induced by Akt/PKB pathway. Islets. 2020;12: 32-40. https://doi.org/10.1080/19382014.2020.1762471

25. Glavas MM, Hui Q Tudurí E, Erener S, Kasteel NL, Johnson JD, et al. Early overnutrition reduces Pdx1 expression and induces $\beta$ cell failure in Swiss Webster mice. Sci Rep. 2019;9: 3619. https://doi.org/10.1038/ $\underline{\text { s41598-019-39177-3 }}$ 
26. Jiang H, Feng J, Du Z, Zhen H, Lin M, Jia S, et al. Oral administration of soybean peptide Vglycin normalizes fasting glucose and restores impaired pancreatic function in Type 2 diabetic Wistar rats. J Nutr Biochem. 2014;25: 954-963. https://doi.org/10.1016/i.jnutbio.2014.04.010

27. Liu Y, Weng W, Wang S, Long R, Li H, Li H, et al. Effect of $\gamma$-Aminobutyric Acid-Chitosan Nanoparticles on Glucose Homeostasis in Mice. ACS Omega. 2018;3: 2492-2497. https://doi.org/10.1021/acsomega.7b01988

28. Leibowitz G, Ferber S, Apelqvist A, Edlund H, Gross DJ, Cerasi E, et al. IPF1/PDX1 deficiency and beta-cell dysfunction in Psammomys obesus, an animal With type 2 diabetes. Diabetes. 2001;50: 1799-1806. https://doi. org/10.2337/diabetes.50.8.1799
29. Herawati L, Wigati KW, Rejeki PS, Widjiati W, Irawan R. Increased apoptosis, but not pancreatic duodenal homeobox-1 expression in pancreatic islets is associated with intermittent glucose loads in mice. Diabetes mellitus. 2019;21: 497-505. https://doi.org/10.14341/DM9437

30. Untereiner A, Abdo S, Bhattacharjee A, Gohil H, Pourasgari $\mathrm{F}$, Ibeh $\mathrm{N}$, et al. GABA promotes $\beta$-cell proliferation, but does not overcome impaired glucose homeostasis associated with diet-induced obesity. FASEB J. 2019;33: 3968-3984. https://doi.org/10.1096/fj.201801397R 